\title{
9. VARIATIONS IN ULTRASONIC VELOCITY AND DENSITY WITH PORE PRESSURE IN THE DÉCOLLEMENT ZONE, NORTHERN BARBADOS RIDGE ACCRETIONARY PRISM ${ }^{1}$
}

\author{
Harold J. Tobin² and J. Casey Moore ${ }^{3}$
}

\begin{abstract}
In a recent three-dimensional multichannel seismic reflection survey, the décollement zone of the northern Barbados Ridge accretionary prism exhibits both negative and positive-polarity, high-amplitude fault plane reflections. The negative-polarity regions of this reflector have been interpreted as a response to elevated fluid pressure with attendant low velocity and density in the fault zone. Here, we use core samples from above, within, and below the décollement at Site 948 on Ocean Drilling Program Leg 156 to evaluate the effect of varying fluid pressure (or effective pressure) conditions on the $P$-wave velocity and density of the samples.

At Site 948, the décollement zone exhibits a positive-polarity fault plane reflection probably caused by a shift to higher density across a lithologic boundary coincident with the décollement zone. The density distribution observed in the borehole and velocities consistent with inferred fluid pressures suggest a positive impedance contrast. The negative-polarity waveform of the reflector below Site 947 requires a low-impedance zone superimposed on this lithologic boundary. Overpressures above estimates for hydrostatic or ambient conditions at Site 948 cause a velocity decrease of $\sim 100-200 \mathrm{~m} / \mathrm{s}$, and a percent porosity increase of up to $\sim 4 \%$. The minimum acoustic impedance measured for the upper part of the décollement is $\sim 2.83 \times 10^{6} \mathrm{Mg} / \mathrm{m}^{2} \mathrm{~s}$ at near-zero effective pressure. Published synthetic seismic models for examples of the negative-polarity reflections require reflection coefficients that imply much lower impedance in this interval. We conclude that significant hydraulic dilation of the fault at lithostatic fluid pressure is necessary to generate the observed reflectivity.
\end{abstract}

\section{INTRODUCTION}

The northern Barbados Ridge accretionary prism now ranks as the most intensively studied prism on earth, with three legs of Deep Sea Drilling Project (DSDP) and Ocean Drilling Program (ODP) drilling, numerous submersible dives, and two- and three-dimensional multichannel seismic reflection (MCS) surveys dedicated to understanding the tectonic, physical, and chemical processes of accretion. The Barbados prism has been characterized as the fine-grained end-member of the continuum of prisms from mud dominated to sand dominated. Its narrow taper and thin incoming sediment section makes the décollement zone at the base of the prism much more accessible to drilling than most. Accretionary prisms in general are among the most tectonically active regions of the earth's crust, with extremely high strain rates and vigorous fluid circulation (Moore and Vrolijk, 1992). One of the main focuses of investigation in accretionary prisms of the past decade has been to define the magnitudes and pathways of fluid flow as pore waters and other fluids are produced and exit the deforming sediments of the prism. A clear conclusion that has emerged from this research is that fluids are predominantly channeled along active thrusts and other faults within the toes of prisms (Moore and Vrolijk, 1992, and citations therein; Tobin et al., 1993). Fluid pressure gradient is the driving force for fluid flow. At the same time, it has been known for decades that high pore-fluid pressure can enable low-angle thrusting (Hubbert and Rubey, 1959).

For these reasons, the primary objectives of Leg 156 were to investigate fluid flow, fluid pressure, and permeability of the décollement zone. Indirect evidence for high fluid pressure and low effective

${ }^{1}$ Shipley, T.H., Ogawa, Y., Blum, P., and Bahr, J.M. (Eds.), 1997. Proc. ODP, Sci. Results, 156: College Station, TX (Ocean Drilling Program).

${ }^{2}$ Geophysics Department, Stanford University, Stanford, CA 94305-2215, U.S.A. tobin@pangea.stanford.edu

${ }^{3}$ Earth Sciences Department, University of California, Santa Cruz, Santa Cruz, CA 95064, U.S.A. stress in the décollement comes from DSDP Leg 78A and ODP Leg 110 , as well as studies of other prisms, including inferences based on structural, geochemical, and other seismic reflection data. The only information available on the distribution of fluid pressure (and possibly flow paths) in the fault zone is inferred from the three-dimensional seismic reflection data set, in which negative-polarity reflections have been proposed to indicate fluid-rich zones (Shipley et al., 1994). Successful hydrologic measurements in the décollement zone were obtained on Leg 156 at Sites 948 and 949 (Fisher et al., 1996), yet drilling and testing of a high-amplitude, negative-polarity fault-zone reflection (attempted at Site 947) proved impossible on operational grounds (see Shipley, Ogawa, Blum, et al., 1995). Lacking such direct observations, indirect means must be employed for estimating the fluid-pressure conditions in the parts of the décollement zone exhibiting negative-polarity reflections. The strategy in this study is to use core samples and log data obtained at Site 948 - which has a positive-polarity fault reflector-to study the $P$-wave velocity and density responses of the sediments to changes in fluid pressure and effective stress conditions. These data are then used to infer the cause of the negative-polarity reflector at Site 947 and elsewhere in the décollement zone. In short, the question addressed here is: given the sediments and structures at Site 948 , what conditions or properties must change to convert the reflection from low-amplitude positive to highamplitude negative polarity?

\section{BACKGROUND}

\section{Fault Plane Reflections}

The acquisition of high quality MCS data in recent years has greatly enhanced the imaging of fault-plane reflectors in accretionary wedges globally and has permitted detailed waveform and amplitude study of those reflections. The Nankai (Moore et al., 1990), Barbados (Westbrook et al., 1988), Costa Rica (Shipley et al., 1990), and Cascadia (MacKay et al., 1992; Moore et al., 1991; Tobin et al., 1994) accretionary prisms include thrust faults showing high-amplitude, 


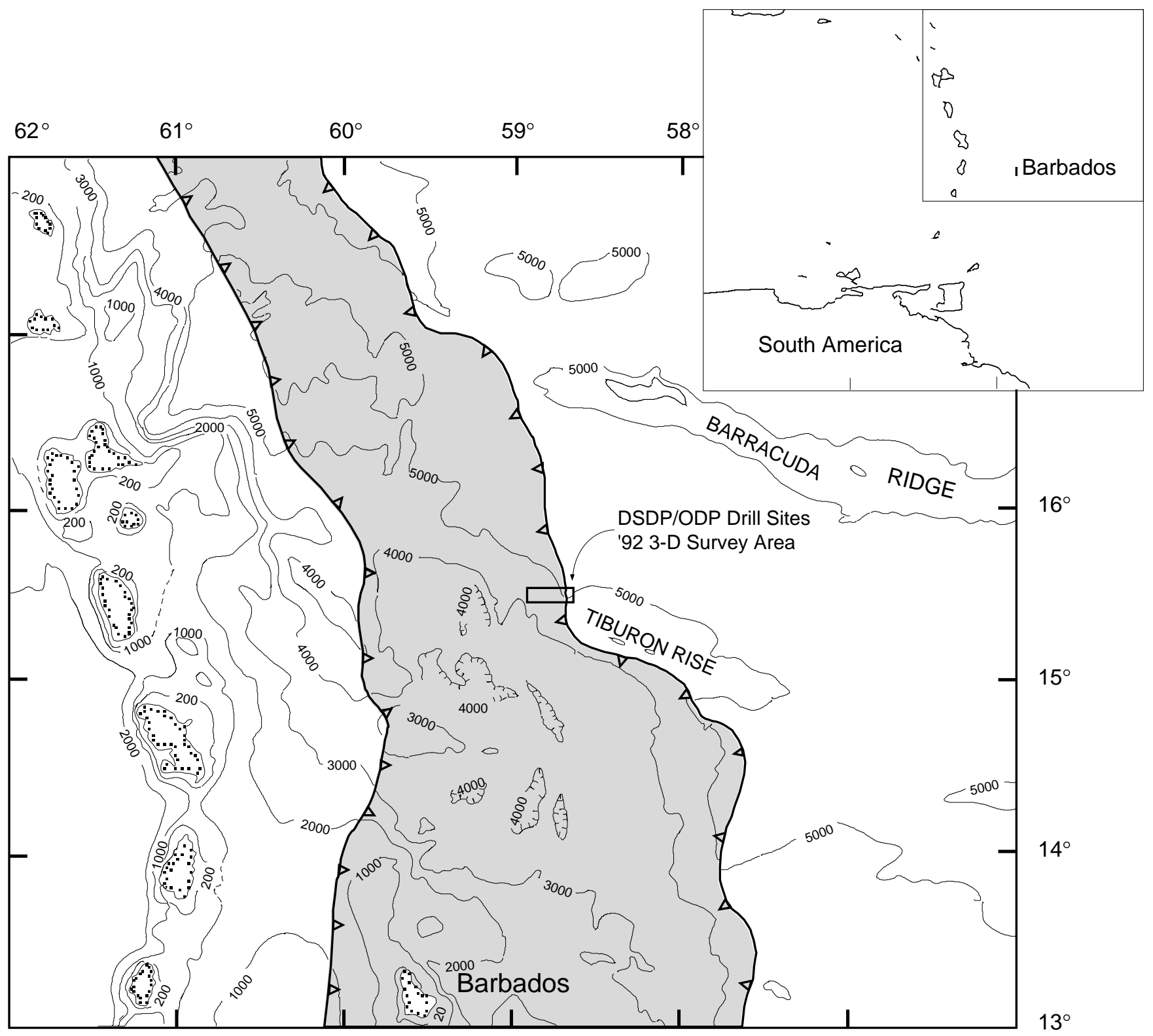

Figure 1. This Page: Location of northern Barbados Ridge accretionary prism and drilling area for Legs 78, 110, and 156. Next Page: Line 688 from threedimensional MCS survey, displayed as a true-amplitude depth section (reproduced from Shipboard Scientific Party, 1995), indicating locations of Sites 947 and 948. Note prominent décollement reflection and phase reversal between Sites 948 and 947.

negative-polarity reflections. Modeling of these reflections suggests that they are of two significantly different types:

1. reflections produced by a simple thrust inversion of higher impedance (product of velocity and density) material overlying lower impedance material (Nankai: Moore and Shipley, 1993; and Costa Rica: Shipley et al., 1990); and

2. a more complex compound reflection resulting from a fault zone of finite thickness, composed of lower impedance material sandwiched between higher impedances above and below.

If this low-impedance zone is thinner than the seismic wavelength, then the result will be a single, compound, reflected wavelet formed of constructively interfering pulses from the top and bottom impedance boundaries (e.g., Cascadia frontal thrust: Tobin et al., 1994; J.C. Moore et al., 1995a). The negative-polarity reflector from the North
Barbados décollement has been shown to be a compound reflection from a thin zone of anomalous impedance (Bangs and Westbrook, 1991; Shipley et al., 1994; Bangs et al., 1996).

Evidence that at least some of these reflections are generated by fault zones of anomalously low velocity and/or density is in some ways puzzling. For example, core samples from the Nankai prism décollement zone (Leg 131, Site 808) show anomalously high density and velocity (Morgan and Karig, 1995). In general, the shear strain at the Barbados décollement causes compactive strain and a modest porosity collapse in the clay-dominated sediments, leading to density increase (Labaume et al., Chapter 4, this volume). Cloos (1984) first proposed that the pervasive fracture systems of wedge thrusts could be high-porosity, fluid-filled zones of low acoustic impedance, dilated and kept open by near-lithostatic pore pressure. Bangs and Westbrook (1991), Shipley et al. (1994), and Moore et al. (1991) have used this concept to explain the apparent paradox, speculating that elevat- 


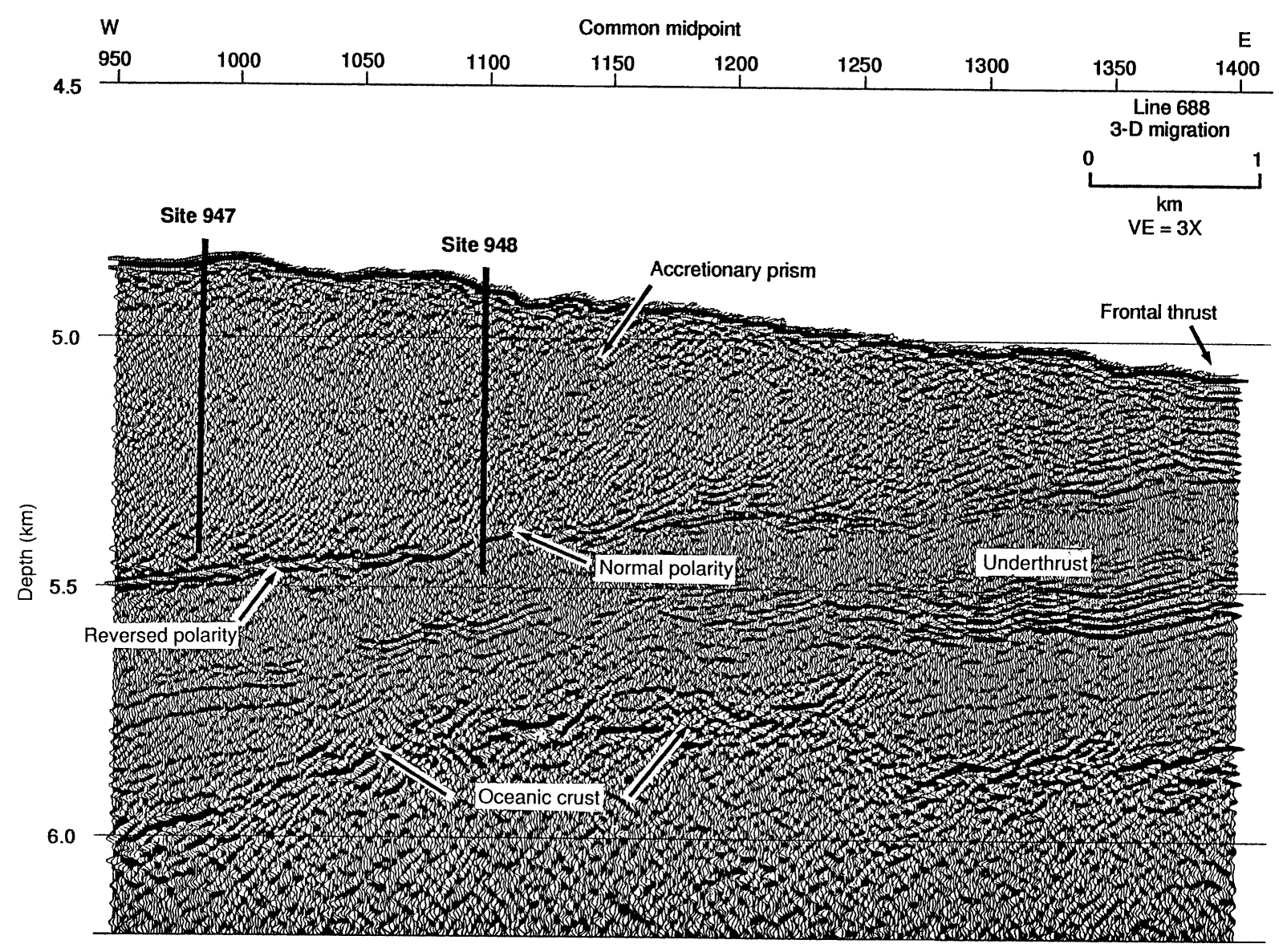

Figure 1 (continued).

ed pressure in fluid migrating along the fault causes dilation of the fractures, resulting in overall low impedance in the fault. Tobin et al. (1994) estimated fault-zone fluid pressure by synthesizing fault reflectivity with velocity vs. effective pressure data for samples from the Cascadia frontal thrust at ODP Site 891. This study showed that overpressures of $86 \%-100 \%$ of lithostatic in a thin $(\sim 10 \mathrm{~m})$ fault zone could produce the observed reflectivity. Although not excluded, neither significant hydrofracture nor dilation was required to cause the reflection, in contrast to previous inferences (Moore et al., 1991).

Here, we present laboratory acoustic data for the very different sediments-but similar reflections-of the Barbados décollement zone. We collected a suite of whole-round samples from the décollement zone at Site 948, as well as the hanging wall and foot wall sediments, with the goal of experimentally determining the dependence of velocity and density on fluid pressure. When compared to models (Bangs et al., 1996) of the seismic impedance of the décollement, results indicate that high-amplitude negative-polarity regions are probably caused by lithostatic fluid pressure and hydraulic dilation of the fault zone.

\section{Tectonic Setting}

The northern Barbados Ridge is the accretionary prism formed forward of the Lesser Antilles arc, where oceanic crust of the North Atlantic portion of the North American Plate is being underthrust beneath the Caribbean Plate at rates between 25 and $40 \mathrm{~km} / \mathrm{m}$.y. (Fig. 1A). In the drilling area, the prism forms a wide, low taper-angle wedge (Fig. 1B), up to $10 \mathrm{~km}$ thick and $120 \mathrm{~km}$ across (Westbrook et al., 1988). Incoming section on the subducting plate is relatively thin in this region $(410 \mathrm{~m}$ at reference Site 543 east of the deformation front), owing in part to the influence of the Tiburon Rise on the deposition of sediments derived from the northern margin of South America. At Site 948 (essentially the same as the previously drilled Site 671), $490 \mathrm{~m}$ of thrust-imbricated, poorly lithified pelagic and hemipelagic muds overlie a 40-m-thick décollement zone, defined by the presence of shear deformation structures (scaly fabric and tectonic breccia) in the cores (Fig. 2). Below the décollement, another $\sim 420$ $\mathrm{m}$ of little-deformed hemipelagic and clastic terrigenous sediment overlies the oceanic basement of the downgoing plate (Mascle, Moore, et al., 1988). The offscraped sediments of the prism are of late Miocene to early Pleistocene age, whereas the drilled interval below the décollement is of Cretaceous to late Oligocene age. The décollement zone is known from pore-water geochemistry to be a site of extremely localized fluid flow (Gieskes et al., 1990; Shipboard Scientific Party, 1995).

Results from drilling on Legs 78A, 110, and 156 indicate that, within a few kilometers arcward of the deformation front, the décollement is consistently localized on the lower Miocene radiolarianbearing hemipelagic clay at the base of lithologic Unit II (Fig. 2; this interval was designated Unit IIC on Leg 110 at Site 671, but Unit IIE on Leg 156 at Site 948). Macroscopically, the décollement strips off the Miocene to lower Pleistocene Units I and II into the prism, and permits the Cretaceous to upper Oligocene Units III and IV to be underthrust beneath the prism without significant deformation. For the purpose of this study, we assume that this fault geometry and the stratigraphy is consistent laterally at least to Site $947,1.7 \mathrm{~km}$ arcward of Site 948.

This assumption of lateral consistency is supported by two independent arguments. First, drilling results at Sites 541, 672, 675, and 676 all indicate that the stratigraphy is correlative over a broad re- 


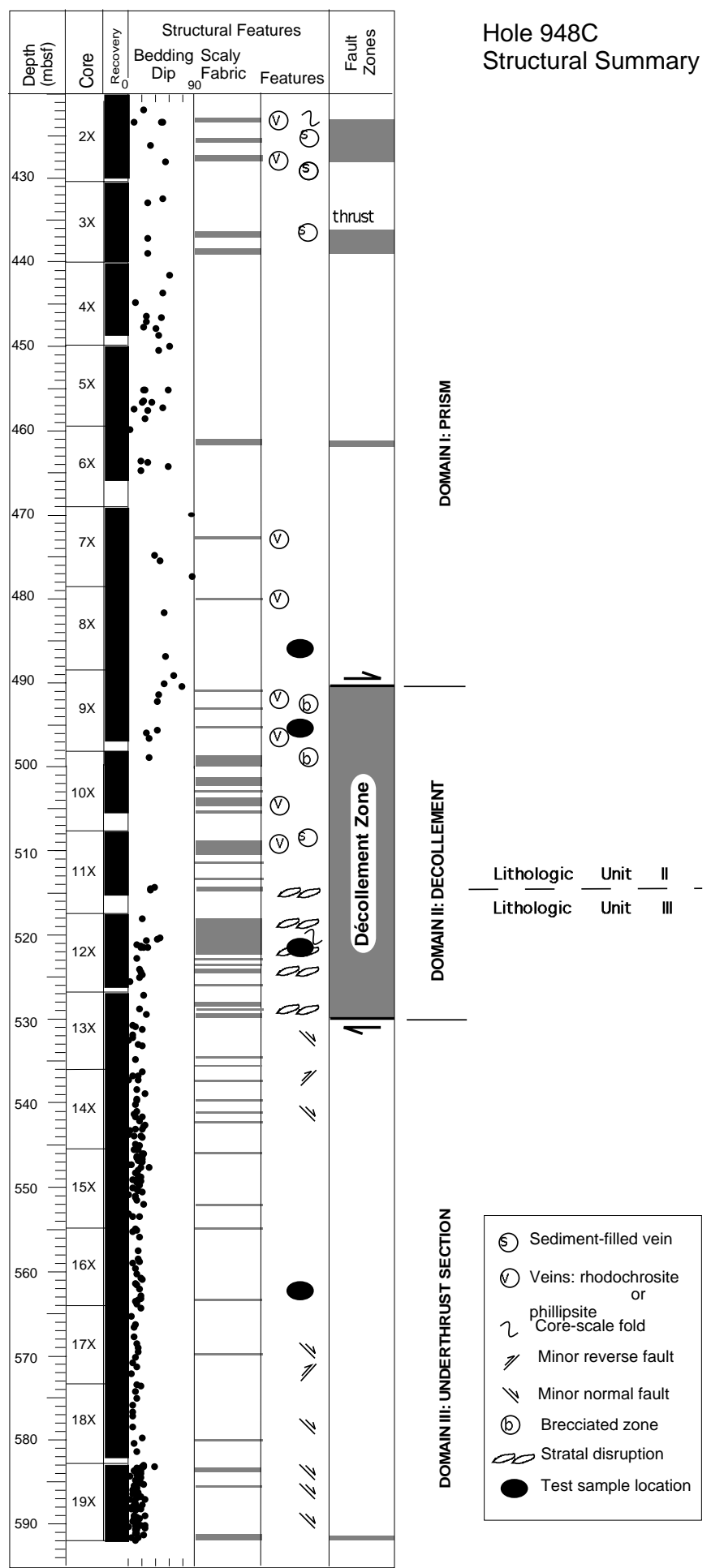

Figure 2. Structural summary log of Site 948 coring, including location of Unit II/III boundary. Locations of tested whole-round samples marked with black ovals.

gion. This is not surprising given the deep-water pelagic and hemipelagic facies, in which depositional complexities such as channeling are much less likely than in the trench turbidite facies of continental margin subduction zones. The units through the décollement section are characterized by slow sedimentation in tranquil water (Shipboard Scientific Party, 1995; Mascle, Moore, et al., 1988). This tends to produce uniform deposition of broad areal extent. Second, an individ- ual reflecting horizon in the seismic data ("Horizon A" of G.F. Moore et al., 1995), interpreted as a stratigraphic horizon, can be traced from the basin into and under the décollement zone. This horizon is traceable under the negative-polarity décollement reflector below Site 947, showing the lateral continuity of the stratigraphy (G.F. Moore et al., 1995).

\section{Décollement Zone Reflectivity}

The décollement zone forms a prominent seismic reflector over much of its extent. A recent study of the character of the décollement reflection in the three-dimensional survey, which includes the drill sites, shows that this reflection is variable in character, with areas of both negative and positive reflection polarity (Shipley et al., 1994). Many of the regions of negative polarity are of unusually high amplitude (Fig. 3), and modeling of an area of negative-polarity reflections somewhat to the south of the drilling transect (Line 630) suggests that they result from a thin interval, associated with the fault zone, of very low impedance (Shipley et al., 1994; Bangs et al., 1996). Through earlier modeling of the décollement reflection in a two-dimensional line approximately $100 \mathrm{~km}$ to the north, Bangs and Westbrook (1991) showed that the reflector there also was likely to represent an anomalously low-impedance zone about 20 m thick. Site 947 was situated within the regionally extensive high-amplitude negative-polarity reflection (Fig. 3). Unfortunately, at Site 947 drilling failed to penetrate through or even into the décollement zone because of poor hole stability, so this reflector remains unsampled.

Regions of the décollement zone that exhibit positive reflection polarity (such as Sites 948 and 671) generally are more limited in areal extent and have peak amplitudes only about half the value of the peak negative values (Fig. 3). It has been proposed that the success in penetrating the fault zone at these sites offers indirect support for the hypothesis that negative-polarity reflections elsewhere result from extreme fluid pressures (Shipley et al., 1994).

\section{EXPERIMENTAL METHODS}

For this study, 15- to 20-cm-long whole-round samples were carefully selected upon core recovery at Site 948 . Whole rounds were chosen to represent the varying lithologies and structural fabrics encountered in this borehole, and were taken from above, within, and below the structurally defined décollement zone (Fig. 2). Whole rounds were immediately sealed into sections of core liner to prevent loss of pore fluids and physical coherency during subsequent transport and handling. After the cruise, five computed tomography (CT) scans of each sample were obtained: two mutually orthogonal longitudinal sections passing through the center of the sample, and three horizontal sections across the core at regularly spaced intervals. These CT-scans clearly image the locations of lithologic breaks, open cracks, and other drilling- and handling-induced damage ("drill biscuit" surfaces), and were invaluable in choosing coherent intervals from the whole rounds for subsample locations.

Whole-round samples were trimmed using a band-saw into approximately cubic subsamples $25 \mathrm{~mm}$ on a side, and were then loaded into a confining vessel fitted with ports allowing independent pore pressure and confining pressure control (Fig. 4). Care was taken to maintain seawater saturation throughout the sample preparation process to minimize induced cracking and other disturbance of the samples. $P$-wave velocity transducers were mounted in the sample endplatens to measure velocity in a vertical path, mimicking vertically incident seismic reflection data acquisition. Significant directional anisotropy of velocity is likely in these samples based on shipboard measurements (Shipboard Scientific Party, 1995), but was not measured in this study because it should not affect the vertically sampled impedance structure. Ultrasonic $P$-wave velocity $\left(v_{\mathrm{p}}\right)$ was measured under constant confining pressure and varying fluid-pressure condi- 


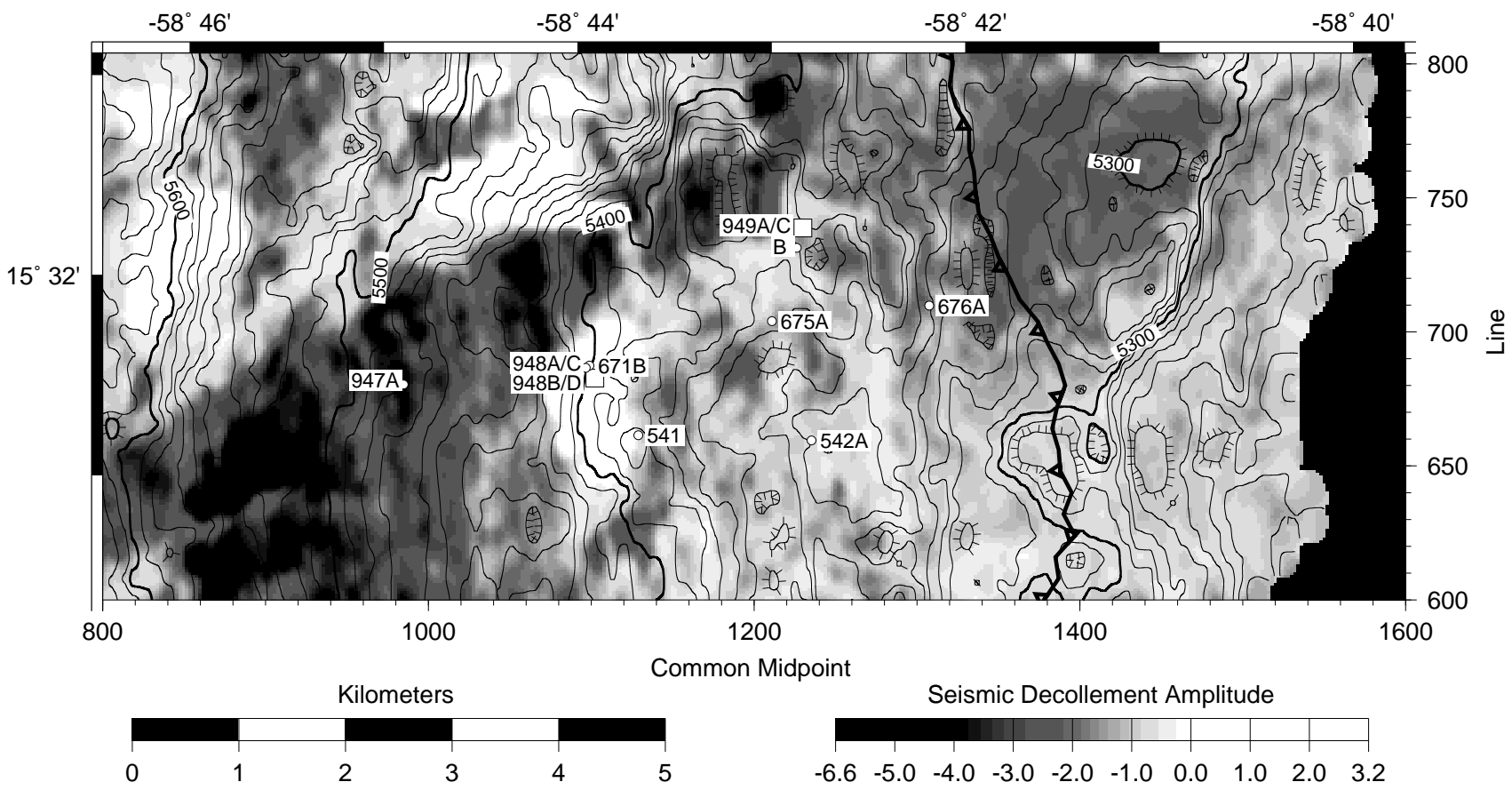

Figure 3. Décollement amplitude map of Shipley et al. (1994). Site 947 is located in a region of high-amplitude negative polarity, where penetration of the reflective zone failed. Site 948 is located on a medium-amplitude, positive reflection, where the fault zone was successfully drilled and sampled.

tions. Internal fluid pressure $\left(P_{\mathrm{f}}\right)$ was controlled by means of a pressure generator ported to the sample, and the pore fluid (seawater) was isolated from the confining medium by a flexible latex membrane placed over the sample and end-platens. The samples were then subjected to isotropic confining pressure $\left(P_{\mathrm{c}}\right)$ equivalent to the calculated lithostatic overburden load given the depth below the seafloor from which the sample was recovered and the density of the overlying sediments. The pressure of the overlying column of water above the seafloor was neglected as it does not contribute to the effective pressure $\left(P_{\text {eff }}\right)$ experienced by the sample.

Isotropic stresses are a reasonable simplification of in situ conditions for the purpose of this study. Both principal horizontal stresses must be at least equal to the overburden load to produce a thrust failure mode, but given the weak, unlithified, and clay-dominated lithologies, differential stresses are likely to be small compared to the mean stress. In any case, vertical $v_{\mathrm{p}}$ is primarily a function of vertical (overburden) stress (Bourbié et al., 1987), lessening the effect of deviations from actual in situ horizontal stress values.

We calculated $v_{\mathrm{p}}$ from pulse-transmission time measurements following methods adapted from Christensen (1985), using 400-kHz ultrasonic transducers, excited by a 400 -ns, 380 -volt pulse produced by a Panametrics 5055PR pulser/receiver. Traveltime was measured using a Hewlett-Packard digital oscilloscope. Error introduced by the frequency difference between ultrasonic and seismic sources was considered negligible (Bourbié et al., 1987). The absolute error of calculated velocity for the samples is within $2 \%$, but relative velocity changes within a given sample are accurate to $\sim 1 \%$. All measurements were made at a temperature of $\sim 20^{\circ} \mathrm{C}$; in situ temperature at the décollement depth is estimated to be $\sim 40^{\circ} \mathrm{C}$ (Shipboard Scientific Party, 1995). Correction for this temperature difference would be slight (<1\%; Bourbié et al., 1987), so none were applied.

Sample pore pressure was controlled independently of $P_{\mathrm{c}}$. For all samples, confining pressure was applied and $P_{\mathrm{f}}$ was simultaneously brought up to $>99 \%$ of $P_{\mathrm{c}}$, (equivalent to essentially lithostatic fluid pressure conditions, or near-zero effective pressure), then $P_{\mathrm{f}}$ was decreased in a step-wise manner down to calculated hydrostatic fluid pressure $\left(P_{\mathrm{h}}\right)$ conditions, and a $v_{\mathrm{p}}$ measurement was taken at each in- crement. Because in situ maximum past fluid pressures are not well known and are likely to be super-hydrostatic, these tests were done on a path of increasing effective pressure so that samples were not subjected to any potential primary consolidation prior to velocity measurement. In this way, individual samples could be used to evaluate velocity variation with effective stress under a wide range of stress conditions, including effective vertical stress greater than in situ values.

This test scheme means that all curves in the data were generated through progressive loading to higher $P_{\text {eff }}$; unloading curves would tend to give higher velocities at a given pressure step if the previous maximum effective pressure is exceeded and inelastic consolidation occurs during the test. Consolidation is a largely irreversible process, and significant velocity hysteresis is expected when preconsolidation stresses are exceeded (e.g., Bowers, 1994). Using progressive loading curves to interpret pressure vs. velocity is conservative in that it predicts lower fluid pressures to achieve a particular velocity reduction than those predicted from unloading curves (Bowers, 1994). Because of the low permeability of these samples, care was taken to allow the internal sample pore pressure to come to equilibrium with the applied pore pressure before recording the traveltime and moving to the next pressure step. This equilibration time varied for the tested samples from 6 to $24 \mathrm{hr}$. Thus, complete testing of a given sample took up to two weeks under continuous confining pressure. For three of the samples, a low-pressure cycle of decreasing and then increasing fluid pressure was run to evaluate the sample behavior during unloading and reloading through the likely range of previous effective pressure.

\section{RESULTS Velocity Data}

Four samples were tested across the décollement and from both major lithologic units (II and III). Interval 156-948C-8X-CC, 12-26 $\mathrm{cm}$, comes from the prism structural domain, above the décollement as defined in the cores. Interval 156-948C-9X-6, 28-43 cm, repre- 


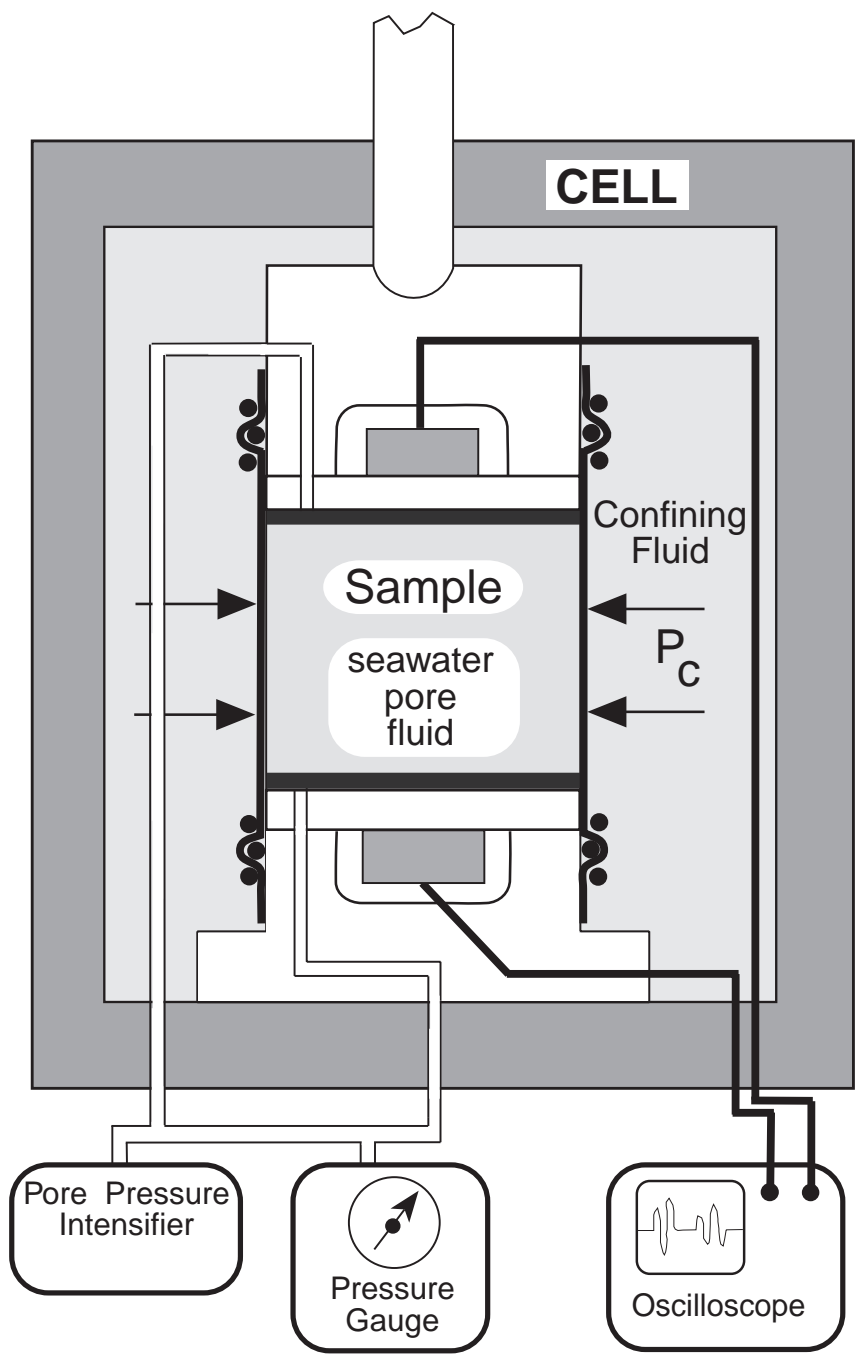

Figure 4. Schematic of sample testing apparatus, not to scale.

sents the upper, most hydrologically active part of the décollement. Interval 156-948C-12X-3, 40-57 cm, exhibits the intense scaly fabric that is the structural hallmark of the décollement, and interval 156$948 \mathrm{C}-16 \mathrm{X}-7,15-31 \mathrm{~cm}$, is from the underthrust section and exhibits no macroscopic deformation features. Lithostatic overburden, calculated hydrostatic pressure, and apparent in situ fluid pressure were extracted from an empirically generated curve (J.C. Moore et al., 1995b; Fig. 5), which is based on density logs and consolidation tests.

Velocity vs. effective pressure data from all four tested samples are presented in Figure 6. Lines labeled "hydrostatic" on the graphs represent $P_{\text {eff }}$, assuming hydrostatic fluid-pressure conditions, calculated from the difference between the lithostatic and hydrostatic pressure trends in Figure 5. The lines labeled "in situ" represent the $P_{\text {eff }}$ for each sample assuming the fluid-pressure curve in Figure 5. Note that "in situ" in all cases indicates substantially lower effective pressure than "hydrostatic" does, as even Site 948 (the supposed low-fluid pressure site) is likely to be overpressured to at least $\lambda=0.8$ at décollement depths (where $\lambda$ is the overpressure ratio, or fluid pressure divided by lithostatic pressure).

Interval $156-948 \mathrm{C}-8 \mathrm{X}-\mathrm{CC}, 12-26 \mathrm{~cm}$, from the prism and clearly above the décollement zone, is from the smectite-rich $(\sim 50 \%$ smectite) Unit IID and does not exhibit scaly fabric or fractures or other macroscopic indications of deformation. The sediment is massive and only incipiently lithified. It shows a relatively flat velocity vs. effective pressure curve (Fig. 6A). The low-effective pressure end of the curve has a velocity of $1700 \mathrm{~m} / \mathrm{s}$, rising to about $1775 \mathrm{~m} / \mathrm{s}$ given

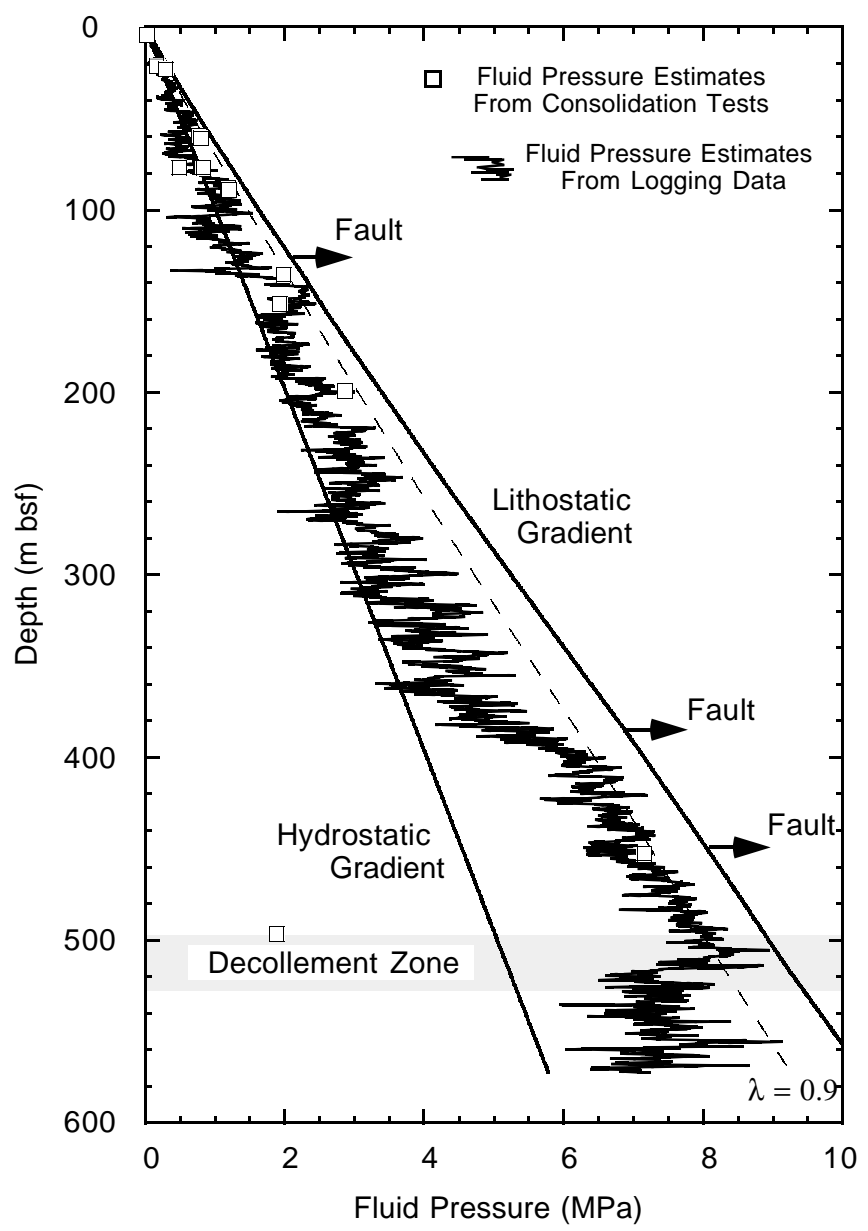

Figure 5. Estimated downhole in situ fluid pressure curve from J.C. Moore et al. (1995b). Fluid-pressure curve is derived from density logs collected by logging-while-drilling, calibrated with consolidation tests from Site 671 samples of Taylor and Leonard (1990). In situ and hydrostatic effective pressures in Figures 6 and 7 are taken from this curve.

fluid pressure as low as hydrostatic, but only to about $1720 \mathrm{~m} / \mathrm{s}$ at assumed in situ pressures. The in situ value of $1720 \mathrm{~m} / \mathrm{s}$ agrees well with sonic log measurements made in the open hole (Shipboard Scientific Party, 1995). Thus, if fluid pressure were to rise toward lithostatic, the maximum velocity decrease predicted would be $\sim 75 \mathrm{~m} / \mathrm{s}$ if hydrostatic background pressure is assumed, and $\sim 20 \mathrm{~m} / \mathrm{s}$ if background pressure from the in situ curve is assumed. The relatively slight shift in velocity with effective pressure by this sample is unusual, and may either result from (1) suppression of full pressure equilibrium and attendant consolidation during the test because of inadequate equilibration time during the test (see Methods section), or alternatively, (2) increased stiffness caused by a relatively high degree of lithification in this interval (such stiffness was qualitatively noted during sampling of this core), attributable to incipient authigenic clay cementation. The latter explanation is supported by the relatively high velocity at near-zero effective pressure shown by this sample.

Interval 156-948C-9X-6, 28-43 cm, comes from $494 \mathrm{~m}$ below seafloor (mbsf), within the uppermost part of the structurally defined décollement zone (as redefined in Housen et al., 1996), and at the depth of the strongest pore-water chlorinity anomaly (Shipboard Scientific Party, 1995). This sample has no scaly fabric but does contain small-scale fractures, in no preferred orientation, at a spacing scale of several millimeters. Otherwise it is massive, incipiently lithified clay. Data from this sample (Fig. 6Bi) shows a velocity vs. $P_{\text {eff }}$ curve ranging from a value of $1620 \mathrm{~m} / \mathrm{s}$ at near-zero effective pressure, to 1810 

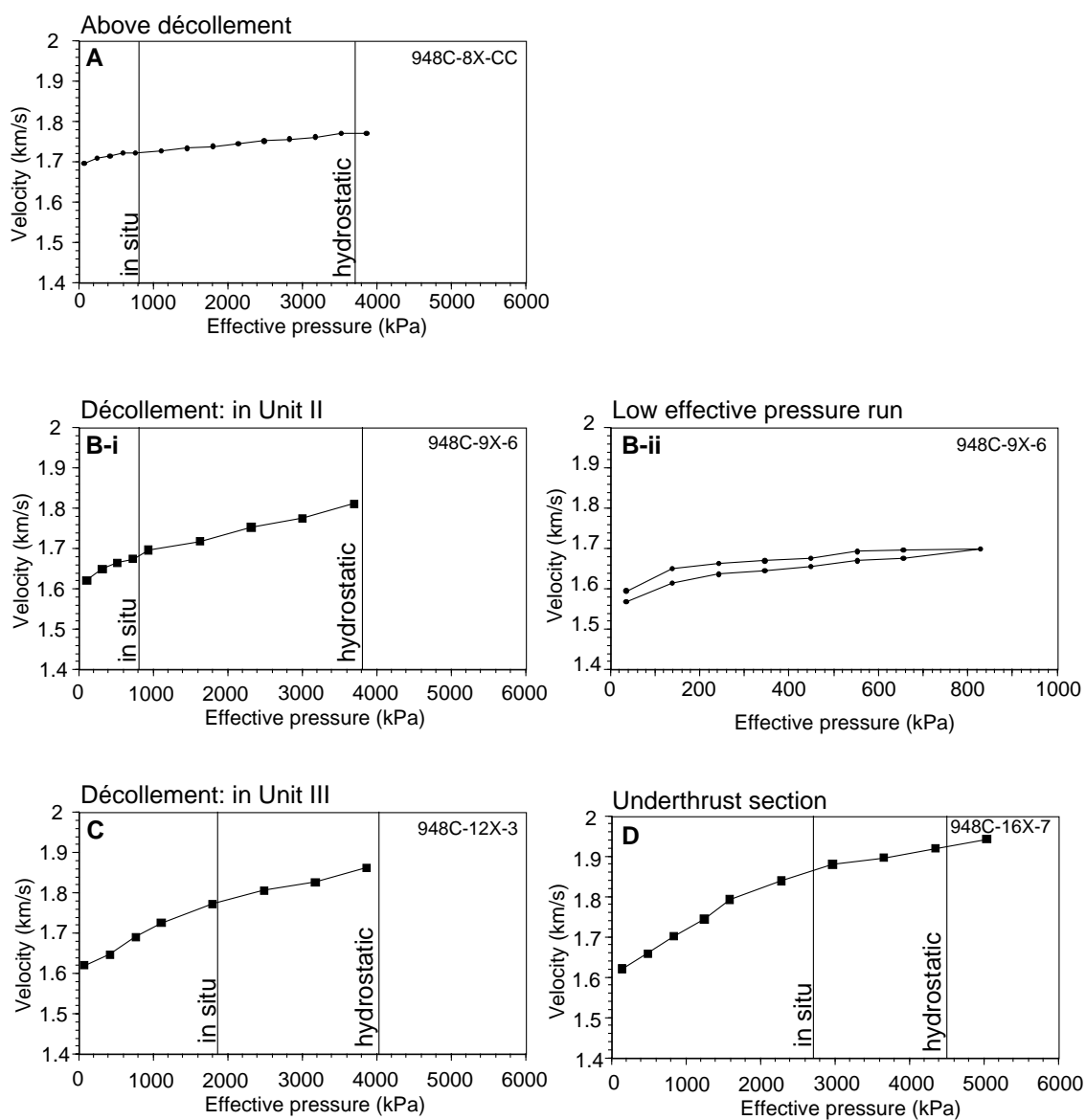

Figure 6. Velocity vs. effective pressure data for all tested samples. A. Section 156-948C-8X-CC. B. Section $156-948 \mathrm{C}-9 \mathrm{X}-6 . \mathbf{i}=$ high effective pressure run, ii $=$ low effective pressure run. C. Section 156-948C12X-3. D. Section 156-948C-16X-7.

$\mathrm{m} / \mathrm{s}$ at $3900 \mathrm{kPa}$. At inferred in situ conditions, velocities of 1680 $1700 \mathrm{~m} / \mathrm{s}$ were recorded. Sonic velocities from logs show a minimum in this interval, with values of $\sim 1700 \mathrm{~m} / \mathrm{s}$, again in agreement with the inferred in situ effective pressure. Prior to loading the sample through the high effective stress range, a loop of effective pressure up to 840 $\mathrm{kPa}$ and back to near zero $(\sim 40 \mathrm{kPa})$ was run to test for differences between the loading and unloading curves (Fig. 6Bii). Hysteresis in this cycle is slight (a maximum of $\sim 2.5 \%$ velocity difference at equivalent pressure), showing that the preconsolidation stress was not exceeded in this low $P_{\text {eff }}$ run. The slightly higher velocities obtained during unloading are attributed to slight crack healing (Bourbié et al., 1987). At the very low $P_{\text {eff }}$ reached in this run, velocity reached values as low as $1600 \mathrm{~m} / \mathrm{s}$; at $800 \mathrm{kPa}$ in situ values, velocity reached $1700 \mathrm{~m} / \mathrm{s}$. Thus the maximum velocity decrease associated with higher pore pressure predicted would be $\sim 100 \mathrm{~m} / \mathrm{s}$ if background pressure using the in situ curve is assumed, and $\sim 200 \mathrm{~m} / \mathrm{s}$ if hydrostatic background pressure is assumed.

Interval 156-948C-12X-3, 40-57 cm (Fig. 6C), is taken from the lower half of the décollement zone, below the Unit II/III boundary, and exhibits intense scaly fabric. Velocity varies from 1620 to 1880 $\mathrm{m} / \mathrm{s}$. At the estimated in situ pressure, velocity is $1780 \mathrm{~m} / \mathrm{s}$. Note that the in situ pressure curve (Fig. 5) undergoes a steep transition to lower fluid pressures in this interval, and the velocity vs. $P_{\text {eff }}$ curve slope is also steep, so uncertainty over the in situ pressure and therefore velocity is relatively large for this sample. Therefore, a reasonable range for in situ velocity is $1740-1780 \mathrm{~m} / \mathrm{s}$.

Finally, interval 156-948C-16X-7, 15-31 cm (Fig. 6D), from the underthrust section, has no macroscopic deformation fabric. It exhibits velocity variations nearly identical to those of Core 156-948C$12 \mathrm{X}$, which has similar lithology but is strongly deformed, suggesting that the lithology rather than the structural fabric controls the shape of the velocity vs. $P_{\text {eff }}$ curve. The velocity varies from 1620 to
$1920 \mathrm{~m} / \mathrm{s}$; at the estimated in situ pressure it is $1840-1860 \mathrm{~m} / \mathrm{s}$. Sonic velocity $\operatorname{logs}$ from this interval average $1700-1750 \mathrm{~m} / \mathrm{s}$, which would correlate to substantially higher fluid pressure and lower effective pressure $(\sim 1000 \mathrm{kPa})$ than that derived from the curve. This deviation from the curve in Figure 5 is not unexpected, as the corrections applied to generate this curve probably are not valid for the underthrust section (J.C. Moore et al., 1995b).

\section{Porosity Data}

Volume change vs. $P_{\text {eff }}$ data were successfully collected during the tests of samples from Cores 156-948C-8X, 9X, and 12X. A slight fluid leak in the testing apparatus external to the cell made these data unusable for Core 156-948C-16X. The volume of fluid expelled from the sample while coming to equilibrium at each pressure step was then converted to a relative change in porosity, assuming a nominal sample porosity based on the physical properties sample value from the shipboard results. Results are presented in Figure 7.

Interval 156-948C-8X-CC, 12-26 cm (prism sample), showed the most modest porosity decrease as effective pressure increased, reaching a maximum of only about $-1.85 \%$ decrease to $3800 \mathrm{kPa}$. In interval 156-948C-9X-6, 28-43 cm (décollement, $494 \mathrm{mbsf}$ ), porosity dropped by $3.6 \%$ to $3700 \mathrm{kPa}$, and in interval 156-948C-12X-3, 40$57 \mathrm{~cm}$ (décollement, $521 \mathrm{mbsf}$ ), by $2.9 \%$ to $3900 \mathrm{kPa}$. The maximum shift in porosity indicates only modest density variations with effective stress at sublithostatic fluid pressures. For example, Section 156948C-9X-6, going from a porosity of $\sim 57 \%$ to $\sim 53.4 \%$, would only change in bulk density from 1.75 to $1.81 \mathrm{~g} / \mathrm{cm}^{3}$. The density shift is proportionately smaller if samples are underconsolidated in situ, as suggested by Site 671 consolidation tests (Taylor and Leonard, 1990), and the density anomalies implicit in Figure 5 (J.C. Moore et al., 1995b). Unloading from in situ estimates of about $\lambda=0.8$ to zero 
$P_{\text {eff }}(\lambda=1.0)$ would yield a porosity change from $56.5 \%$ to $57 \%$, producing a near-negligible density shift of $1.747-1.755 \mathrm{~g} / \mathrm{cm}^{3}$.

All three samples have a similar shape to the porosity-effective pressure curve: an initial very low gradient at low effective pressures, a distinct break in slope, then a linear or near-linear decreasing porosity as pressure rose. The break in slope may be a manifestation of the maximum past effective stress experienced by the sample in situ. This would be analogous to the preconsolidation stress on a standard consolidation test, with the steeper gradient reflecting the transition from reloading to the virgin consolidation curve. It is important to note that these data were collected under isotropic stress rather than the uniaxial strain conditions used in standard consolidation tests; they are not a substitute for yield tests. However, under the high lateral stress conditions expected in the toes of accretionary prisms, this isotropic test may duplicate in situ conditions better than uniaxial consolidation tests. The in situ $P_{\text {eff }}$ derived from the fluid-pressure curve (Fig. 5) has been indicated on each curve in Figure 7 for comparison. The break in slope on the Core $156-948 \mathrm{C}-8 \mathrm{X}$ porosity curve suggests a preconsolidation pressure of $600-700 \mathrm{kPa}$, close to the estimated in situ effective stress value of $800 \mathrm{kPa}$ derived from Figure 5. That of Core 156-948C-9X also agrees well, because the break in slope occurs at $950 \mathrm{kPa}$ or above, and the in situ estimate is $800 \mathrm{kPa}$. Core 156-948C-12X does not fit as well, with the break in slope at $1100 \mathrm{kPa}$ or above, and the in situ estimate at $1850 \mathrm{kPa}$. As discussed in the section above the in situ estimate has an unusually high degree of uncertainty for this sample, and could be substantially lower than $1850 \mathrm{kPa}$. If these curves really do give an indication of the preconsolidation stress, then they support the in situ pressure curve and underconsolidation suggested by J.C. Moore et al. (1995b) and Taylor and Leonard (1990), respectively.

\section{DISCUSSION}

\section{Causes of the Polarity Reversals of the Décollement Zone Reflector}

Using the results of the laboratory velocity and porosity measurements, core-based observations, and comparison to waveform models, we can make several inferences regarding the physical nature of the décollement zone. Everywhere that the sediment column and décollement have been penetrated, the décollement is clearly localized on the base of Unit II (Fig. 2), with deformation extending tens of meters both above and below the Unit II/III boundary (Mascle and Moore, 1990). We believe that it is reasonable to assume that this holds true in the nearby regions of negative polarity as well, because stratigraphic horizons can be traced laterally from positive- to negative-polarity regions (G.F. Moore et al., 1995). Using this assumption, we consider the possible physical cause of the polarity reversals based on the data from Site 948.

At Site 948, the fault zone is recognized in cores as a 40-m-thick zone of well-developed scaly fabric and tectonic brecciation. The lithologic boundary of Units II and III occurs in the middle of this zone of scaly fabric, with deformation on both sides of the boundary. At calculated in situ pressures, there is a slight $(\sim 50 \mathrm{~m} / \mathrm{s})$ decrease in the acoustic velocity in the upper part of the fault zone compared to superjacent sediment, attributed here to the deformation in the faultzone sample. This velocity decrease is overshadowed by the prominent shift to higher density across the lithologic boundary as seen in both core physical properties data and logging-while-drilling (LWD) density logs (Shipboard Scientific Party, 1995). At this site, there is no negative-polarity reflection; we attribute the positive reflection (Fig. 8) to this density increase. A synthetic seismogram based on the density log reproduced this positive-polarity reflection (Shipboard Scientific Party, 1995). The density log also shows two very thin $(<3$ $\mathrm{m}$ ) intervals of anomalously low density at 505 and $514 \mathrm{mbsf}$, interpreted by J.C. Moore et al. (1995b) as hydrofractures filled with fluidized sediment. These apparent low-density zones are too thin to be resolved as reflections.

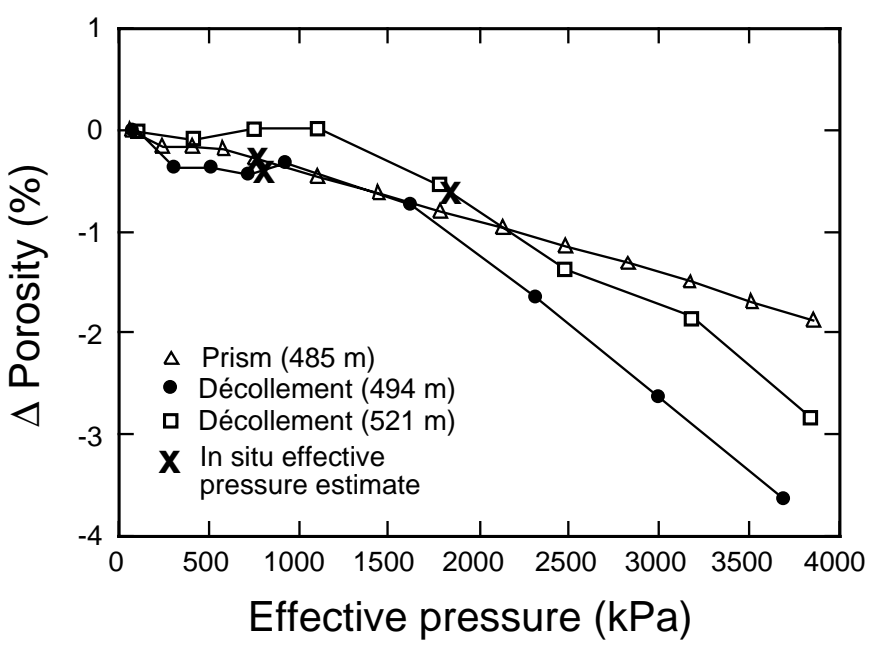

Figure 7. Porosity vs. effective pressure for all tested samples, expressed as the percent change from initial porosity as effective pressure was increased.

To produce large-amplitude negative-polarity reflections such as the one under Site 947 (Fig. 9), assuming the same lithologic column and similar structural geology of the décollement zone, some physical property has to change. Previous research (Bangs and Westbrook, 1991; Shipley et al., 1994; Tobin et al., 1994; J.C. Moore et al., 1995a) has shown that the most likely property change that can affect the impedance so strongly in a fault zone is for the fluid pressure (and therefore $P_{\text {eff }}$ ) to vary. We first consider the physical cause of negative polarity with this uniform lithology assumption, then possible scenarios that deviate from this assumption.

Bangs et al. (1996) presented waveform and amplitude models of strongly negative-polarity regions of the décollement-zone reflection. The impedance structure of the zone is remarkably consistent. The moderate- to high-amplitude reflections they modeled are fit by a low-velocity zone $12-16 \mathrm{~m}$ thick, with a velocity decrease relative to the immediately overlying material of $100-200 \mathrm{~m} / \mathrm{s}$. The highamplitude reflections require a velocity decrease of $150-200 \mathrm{~m} / \mathrm{s}$, assuming density varies according to relations in Hamilton (1978). This combination of velocity and density corresponds to upper boundary reflection coefficients of -0.09 to -0.12 .

If we assume that the only difference between the décollement at Site 948 and the regions of negative polarity is fluid pressure, we can use the laboratory data to place bounds on the magnitude of overpressure. Driving fluid pressure to the near-lithostatic maximum for Core $156-948 \mathrm{C}-9 \mathrm{X}$ would produce a velocity drop of $100 \mathrm{~m} / \mathrm{s}$ and a density change that is less than $0.1 \mathrm{~g} / \mathrm{cm}^{3}$, as discussed above. This impedance structure would produce a moderate-amplitude, negative-polarity reflection at the décollement zone. The amplitude modeling of Bangs et al. (1996) $2-3 \mathrm{~km}$ to the southwest of the drill sites indicates a velocity drop of 150-200 m/s, but assumes a much larger density decrease associated with the velocity change, following a Hamilton (1978) function coupling density to velocity. This empirical function is appropriate for normal depth-dependent consolidation of sediments, but overestimates density variations with velocity in sediments undergoing unloading through rising pore pressure (Bowers, 1994). If density is allowed to vary only slightly, as indicated by the data presented here, then much larger velocity reduction would be required than can be supported by the measured values at positive effective pressures.

The ambiguity resulting from this trade-off between velocity and density can be addressed by considering contrasts in acoustic impedance, rather than just velocity or density. The impedance dependence on effective pressure can be calculated using the measured velocity and volume change data, transforming the volumetric data to density change (Fig. 10). Using the plotted acoustic impedance values, the impedance drop necessary to obtain the reflection coefficients pre- 
Site 948

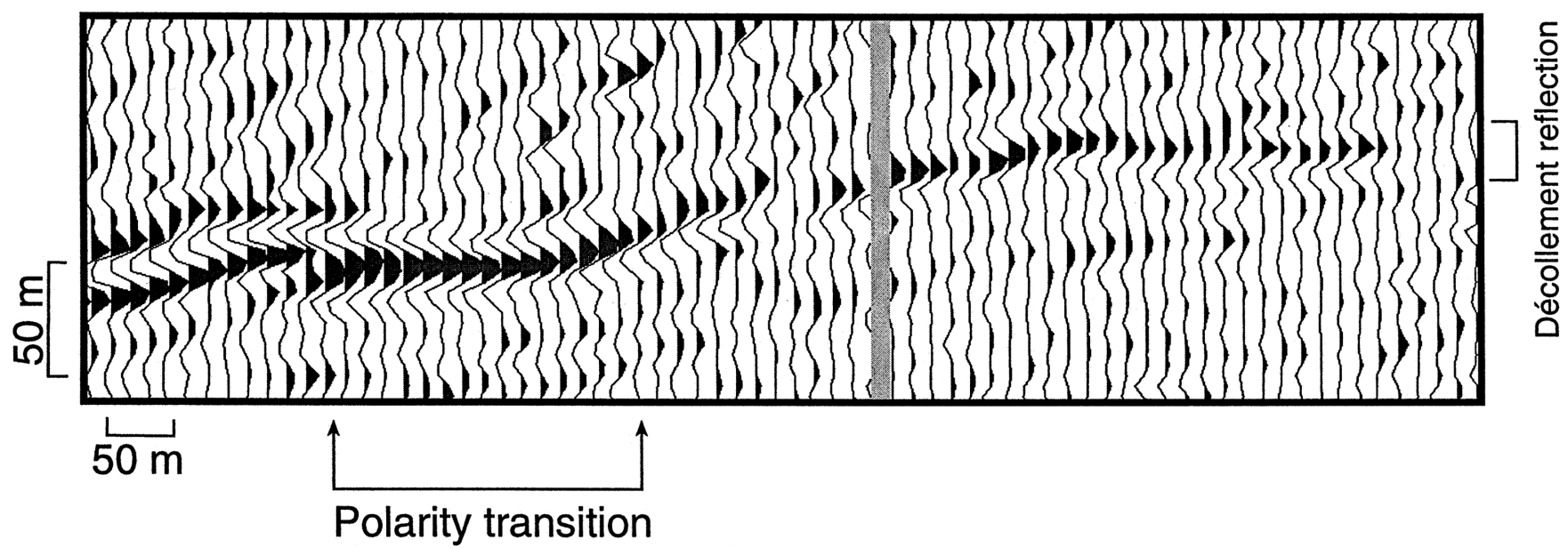

Figure 8. Detail of Line 688 of the three-dimensional MCS survey, showing the décollement reflection at Site 948, depth migrated, where the fault exhibits positive-polarity reflection. Note transition to negative polarity in left (west) half of display.

Site 947: LWD hole

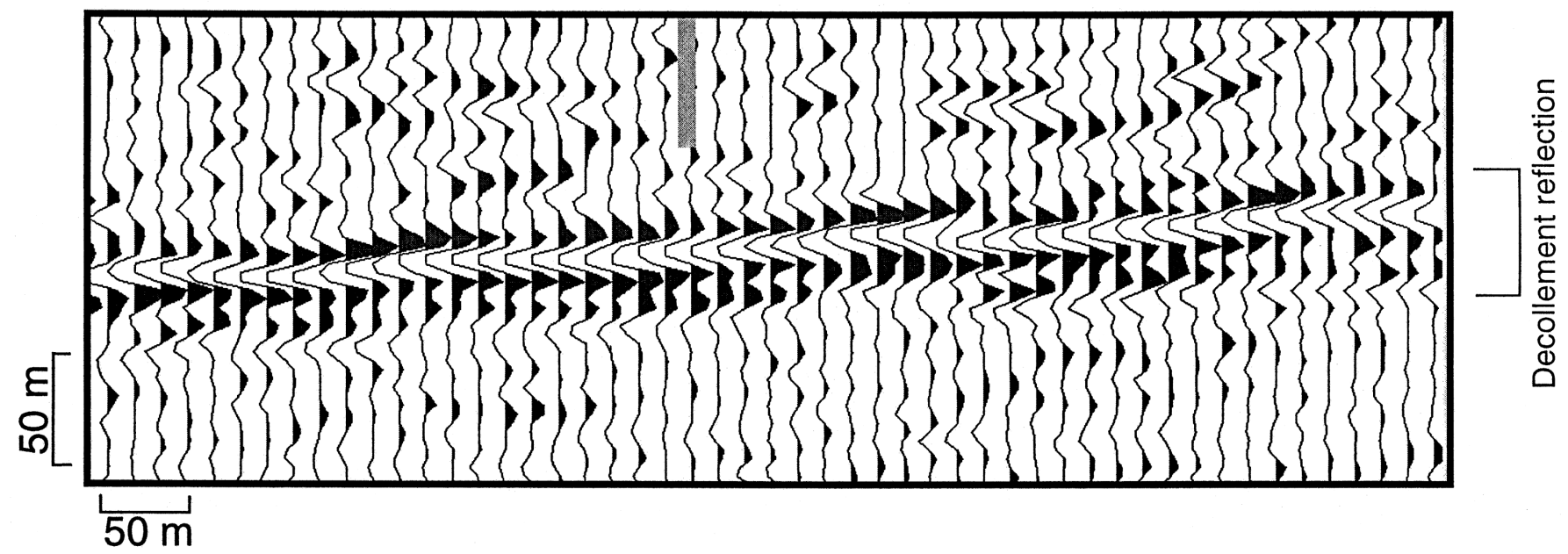

Figure 9. Detail of Line 688 of the three-dimensional MCS survey, showing the décollement reflection at Site 947, depth migrated, where the fault zone exhibits a high-amplitude negative polarity.

dicted by Bangs et al. (1996) can then be evaluated. The prism sample representing the zone above the reflector has an in situ impedance value of 2.94 (impedance units of $\mathrm{Mg} / \mathrm{m}^{2} \mathrm{~s} \times 10^{6}$ ). A layer placed below this would have to have an impedance between 2.45 and 2.31 to induce reflection coefficients between -0.09 and -0.12 , as calculated above. The upper décollement core (Core 156-948C-9X) has a minimum acoustic impedance of 2.83 under testing conditions to $99 \%$ of lithostatic, which would yield a reflection coefficient of only -0.019 . If velocity in this sample were to go to the extreme lower bound of $1500 \mathrm{~m} / \mathrm{s}$ (water velocity), the density implied for the reflection coefficients above would range from 1.54 to $1.63 \mathrm{~g} / \mathrm{cm}^{3}$. These densities are comparable to seafloor sediments, as well as to those recorded in thin intervals in the logs, interpreted as hydraulically dilated zones (J.C. Moore et al., 1995b).

We conclude that the bulk velocity and density of the fault zone must be decreased dramatically by values not obtainable even at high overpressure in sublithostatic fluid-pressure conditions. The laboratory velocity and porosity vs. effective pressure data can support a small to moderate negative-polarity reflector with high overpressure, but of insufficient reflection coefficient to reproduce the amplitude of the reflections modeled by Bangs et al. (1996). The high amplitude can be best explained if a zone of very low effective impedance is introduced. At lithostatic fluid pressure, with no effective normal stress (vertical) across the subhorizontal fractures of the décollement zone to keep them closed, fluid-filled hydrofractures may open, decreasing both velocity and density toward water values of $1500 \mathrm{~m} / \mathrm{s}$ and 1.04 $\mathrm{g} / \mathrm{cm}^{3}$ respectively. At any positive effective normal stress such fractures should remain closed, so dilatant hydrofractures are an indication of lithostatic pore pressure. Evidence for the existence of such fluid-filled zones is seen in the LWD results from both Sites 948 and 947. At Site 948, two zones of 1-2 m thickness in the décollement show anomalously low density, as described above, and at Site 947, drilling terminated because of difficulty of penetration and sticking in a zone between 540 and 570 mbsf (just above the décollement reflector) where densities as low as $1.5 \mathrm{~g} / \mathrm{cm}^{3}$ were recorded. J.C. Moore et al. (1995b) concluded that these densities could only be attributed to numerous open fractures dramatically increasing the bulk porosity of the sediment at these depths.

Even if our assumption of uniform lithology laterally away from Site 948 is in error, the apparent extremely low impedance in the re- 


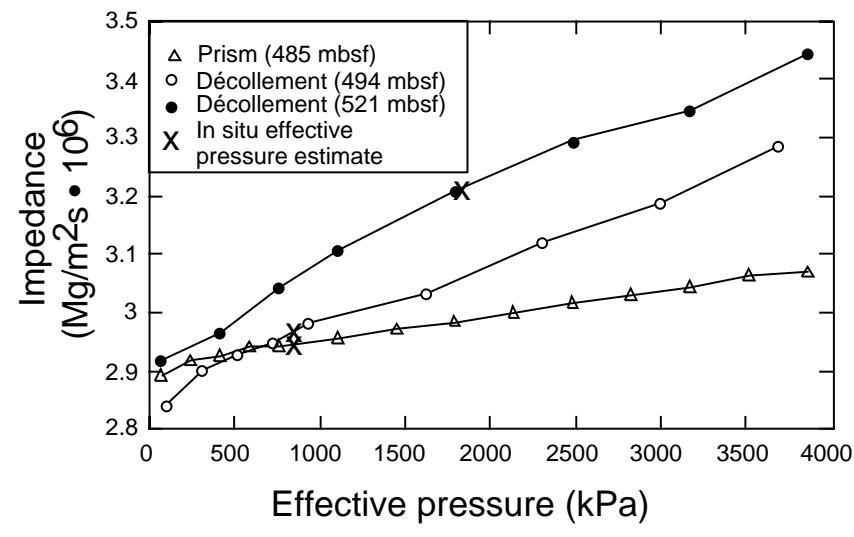

Figure 10. Acoustic impedance vs. effective pressure for all samples, calculated from velocity and porosity data.

flective zone could not result from some more normally pressured alternate lithology. Regardless of lithology, sediment buried to $\sim 500 \mathrm{~m}$ depth would not retain physical properties and impedance equivalent to seafloor sediments except under conditions of extreme underconsolidation.

Another possibility is that significant variations in cementation from one region to another may contribute to the reflectivity. For example, a strongly cemented zone above a normal weakly cemented zone might produce a strong negative-polarity reflection. There are several arguments against the reflections being due to a high-velocity, strongly-cemented layer above the impedance boundary, although the possibility cannot be ruled out entirely in the absence of cores or logs through a negative-polarity zone. LWD logs from Site 947 reached within several tens of meters above the décollement reflection, and found no evidence for anomalous cementation at that site (Shipley, Ogawa, Blum, et al., 1995). Density and resistivity are anomalously low at the bottom of the hole at Site 947, consistent with high porosity and similar to the Site 948 trends (Shipboard Scientific Party, 1995). If there were a strongly cemented zone below the depth of penetration of LWD logs, it ought to produce a positive reflection, which was not observed. The cores from Sites 671 and 948 (and all other sites in the region) do not exhibit matrix cementation by carbonates or silicates, although very rare millimeter-scale veins in the décollement zone have been observed (Labaume et al., Chapter 4, this volume). Rather, cementation of the sediments of the prism and décollement takes the form of incipient authigenic clay mineral growth, lending "structure" (in the geotechnical sense; Leroueil and Vaughan, 1990) to the clayey matrix. As discussed above, there is some evidence that the sample from just above the décollement may be strengthened by such incipient cementation (relative to deformed material below in the fault zone), but the resulting velocity contrast is small. At isostress conditions, the core samples within the fault zone have velocities within $\pm 80 \mathrm{~m} / \mathrm{s}$ of those above and below. We attribute the lower velocity of the upper décollement core (Core 156948C-9X) compared to the overlying prism core (Core 156-948C$8 \mathrm{X}$ ) primarily to the increased presence of fractures, but the destruction of incipient clay matrix cementation may also play a role (Karig, 1993). These observations, coupled with the lack of a positive-polarity reflection from the top of a high-impedance cemented layer, all argue against this scenario; however, this possibility cannot be absolutely ruled out.

\section{CONCLUSIONS}

The primary conclusion to be drawn from this study is that variations in fluid pressure between hydrostatic and lithostatic produce variations in velocity and density of the sediments, but the impedance reduction as fluid pressure rises to $>99 \%$ of lithostatic overburden is still not enough to explain the large negative-polarity reflectivity of much of the décollement zone. If our assumption is correct that décollement stratigraphy and structure varies little in this region, then fluid pressure equal to lithostatic overburden is probably necessary to cause the reflection. Only lithostatic overpressure can induce the hydraulic fracturing and dilation of the sediments necessary to reduce impedance dramatically.

At derived in situ pore pressures without hydrofracture, the deformation of the Site 948 fault zone appears to cause a slight $(\sim 50 \mathrm{~m} / \mathrm{s})$ decrease in the acoustic velocity compared to superjacent sediment lacking macroscopic deformational fabric, attributed primarily to the increased fracture content. This effect is juxtaposed with a significantly larger impedance contrast produced by the change in density at the stratigraphic boundary, which dominates the seismic reflection at Site 948 . The combination of this boundary and the small velocity increase explains the positive reflectivity of the décollement at Site 948.

The models of Bangs et al. (1996) for the strongest negativepolarity reflections similar to those at Site 947 require upper boundary reflection coefficients of -0.09 to -0.12 in the décollement zone. Assuming uniform lithology and a background in situ overpressure similar to that at Site 948, with a pore-pressure rise (i.e., unloading) in the décollement zone, these reflection coefficients cannot be explained except by calling for lithostatic fluid pressure and bulkdensity reduction resulting from hydraulic dilation within the décollement itself. This dilation is most likely manifested as the opening of many of the numerous subhorizontal thin fractures inherent in the scaly fabric exhibited by the cores at Sites 671 and 948.

\section{ACKNOWLEDGMENTS}

Walter Schillinger provided critical assistance with the laboratory design and equipment. The assistance of Greg Moore has been very helpful in interpreting seismic data. We are grateful to Louis Castanier of the Petroleum Engineering Department at Stanford for providing the machine time and assistance with CT scans free of charge. This study could never have been done without the work of numerous shipmates aboard the JOIDES Resolution on Leg 156, including the scientific party, marine technicians, captain, and crew. This work has been supported by JOI Grant 443226-57434 and NSF Grant OCE9116350 .

\section{REFERENCES}

Bangs, N.L.B., Shipley, T.H., and Moore, G.F., 1996. Elevated fluid pressures and fault zone dilation inferred from seismic models of the northern Barbados Ridge décollement. J. Geophys. Res., 101: 627-642.

Bangs, N.L.B., and Westbrook, G.K., 1991. Seismic modeling of the décollement zone at the base of the Barbados Ridge accretionary complex. $J$. Geophys. Res., 96: 3853-3866.

Bourbié, T., Coussy, O., and Zinszner, B., 1987. Acoustics of Porous Media: Paris (Ed. Technip.).

Bowers, G.L., 1994. Pore pressure estimation from velocity data: accounting for overpressure mechanisms besides undercompaction. IADC/SPE Drill. Conf. Proc., 515-530.

Christensen, N.I., 1985. Measurements of dynamic properties of rock at elevated temperatures and pressures. In Pincus, H.J., and Hoskins, E.R. (Eds.), Measurements of Rock Properties at Elevated Pressures and Temperatures: Philadelphia (Am. Soc. for Testing and Materials), ASTM STP 869:93-107.

Cloos, M., 1984. Landward-dipping reflectors in accretionary wedges: active dewatering conduits? Geology, 12:519-522.

Fisher, A., Zwart, G., and ODP Leg 156 Scientific Party, 1996. Relation between permeability and effective stress along a plate-boundary fault, Barbados accretionary complex. Geology, 24:307-310. 
Gieskes, J.M., Blanc, G., Vrolijk, P., Elderfield, H., and Barnes, R., 1990. Interstitial water chemistry-major constituents. In Moore, J.C., Mascle, A., et al., Proc. ODP, Sci. Results, 110: College Station, TX (Ocean Drilling Program), 155-178.

Hamilton, E.L., 1978. Sound velocity-density relations in sea-floor sediments and rocks. J. Acoust. Soc. Am., 63:366-377.

Housen, B.A., Tobin, H.J., Labaume, P., Leitch, E.C., Maltman, A.J., and ODP Leg 156 Shipboard Science Party, 1996. Strain decoupling across the décollement of the Barbados accretionary prism. Geology, 24:127130.

Hubbert, M.K., and Rubey, W.W., 1959. Role of fluid pressures in mechanicas of overthrust faulting, Part 1. Mechanics of fluid-filled porous solids and its application to overthrust faulting. Geol. Soc. Am. Bull., 70:115166.

Karig, D.E., 1993. Reconsolidation tests and sonic velocity measurements of clay-rich sediments from the Nankai Trough. In Hill, I.A., Taira, A., Firth, J.V., et al., Proc. ODP, Sci. Results, 131: College Station, TX (Ocean Drilling Program), 247-260.

Lerouiel, S., and Vaughan, P.R., 1990. The general and congruent effects of structure in natural soils and rocks. Geotechnique, 40:467-488.

MacKay, M.E., Moore, G.F., Cochrane, G.R., Moore, J.C., and Kulm, L.D., 1992. Landward vergence and oblique structural trends in the Oregon margin accretionary prism: implications and effect on fluid flow. Earth Planet. Sci. Lett., 109:477-491.

Mascle, A., and Moore, J.C., 1990. ODP Leg 110: tectonic and hydrologic synthesis. In Moore, J.C., Mascle, A., et al., Proc. ODP, Sci. Results, 110: College Station, TX (Ocean Drilling Program), 409-422.

Mascle, A., Moore, J.C., et al., 1988. Proc. ODP, Init. Repts., 110: College Station, TX (Ocean Drilling Program).

Moore, G.F., and Shipley. T.H., 1993. Character of the décollement in the Leg 131 area, Nankai Trough. In Hill, I.A., Taira, A., Firth, J.V. et al., Proc. ODP, Sci. Results, 131: College Station, TX (Ocean Drilling Program), 73-82.

Moore, G.F., Shipley, T., Karig, D., and Taira, A., 1990. Structural geometry at the toe of the Nankai accretionary prism from MCS and ESP data. $J$. Geophys. Res., 95:8753-8765.

Moore, G.F., Zhao, Z., Shipley, T.H., Bangs, N., and Moore, J.C., 1995. Structural setting of the Leg 156 area, northern Barbados Ridge accretionary prism. In Shipley, T.H., Ogawa, Y., Blum, P., et al., Proc. ODP, Init. Repts., 156: College Station, TX (Ocean Drilling Program), 13-27.

Moore, J.C., Brown, K.M., Horath, F., Cochrane, G., MacKay, M., and Moore, G., 1991. Plumbing accretionary prisms: effects of permeability variations. Philos. Trans. R. Soc. London A, 335:275-288.

Moore, J.C., Moore, G.F., Cochrane, G.R., and Tobin, H.J., 1995a. Negativepolarity seismic reflections along faults of the Oregon accretionary prism: indicators of overpressuring. J. Geophys. Res., 100:12895-12906.
Moore, J.C., Shipley, T.H., Goldberg, D., Ogawa, Y., Filice, F., Fisher, A., Jurado, M.-J., Moore, G.F., Rabaute, A., Yin, H., Zwart, G., and Bruckmann, W., 1995b. Abnormal fluid pressures and fault zone dilation in the Barbados accretionary prism: evidence from logging while drilling. Geology, 23:605-608.

Moore, J.C., and Vrolijk, P., 1992. Fluids in accretionary prisms. Rev. Geophys., 30:113-135.

Morgan, J.K., and Karig, D.E., 1995. Décollement processes at the Nankai accretionary margin, southeast Japan: propagation, deformation, and dewatering. J. Geophys. Res., 100:15,221-15,231.

Shipboard Scientific Party, 1995. Site 948. In Shipley, T.H., Ogawa, Y., Blum, P., et al., Proc. ODP, Init. Repts., 156: College Station, TX (Ocean Drilling Program), 87-192.

Shipley, T.H., Moore, G.F., Bangs, N.L., Moore, J.C., and Stoffa, P.L., 1994 Seismically inferred dilatancy distribution, northern Barbados Ridge décollement: implications for fluid migration and fault strength. Geology, 22:411-414.

Shipley, T.H., Ogawa, Y., Blum, P., et al., 1995. Proc. ODP, Init. Repts., 156: College Station, TX (Ocean Drilling Program).

Shipley, T.H., Stoffa, P.L., and Dean, D.F., 1990. Underthrust sediments, fluid migration paths, and mud volcanoes associated with the accretionary wedge off Costa Rica: Middle America trench. J. Geophys. Res., 95:8743-8752.

Taylor, E., and Leonard, J., 1990. Sediment consolidation and permeability at the Barbados forearc. In Moore, J.C., Mascle, A.,et al., Proc. ODP, Sci. Results, 110:College Station, TX (Ocean Drilling Program), 289-308.

Tobin, H.J., Moore, J.C., MacKay, M.E., Orange, D.L., and Kulm, L.D., 1993. Fluid flow along a strike-slip fault at the toe of the Oregon accretionary prism: implications for the geometry of frontal accretion. Geol. Soc. Am. Bull., 105:569-582.

Tobin, H.J., Moore, J.C., and Moore, G.F., 1994. Fluid pressure in the frontal thrust of the Oregon accretionary prism: experimental constraints. Geology, 22: 979-982.

Westbrook, G.K., Ladd, J.W., Buhl, P., Bangs, N., and Tilley, G.J., 1988. Cross section of an accretionary wedge: Barbados Ridge complex. Geology, 16:631-635.

Date of initial receipt: 1 February 1996

Date of acceptance: 8 July 1996

Ms 156SR-018 